\title{
Eraso Belalcázar, Mario Enrique. Poesía de Roberto Juarroz. La comunión de las formas (2017): Medellín: Universidad de Antioquia, pp. 136.
}

\author{
Alexis Uscátegui Narváez \\ Universidad Mariana \\ auscategui@umariana.edu.co \\ doi.org/10.17533/udea.lyl.n75a11
}

$\mathrm{M}$ ario Enrique Eraso Belalcázar es profesor de literatura de la Universidad de Nariño. Como crítico y poeta se ha interesado sobremanera en estudiar la obra del argentino Roberto Juarroz (1925-1995), publicando diversos estudios en revistas especializadas. En su más reciente trabajo dedicado al poeta en mención, Eraso (2017) expresa: «he intentado analizar las huellas de verticalidad en el itinerario de la escritura juarrociana. Lo profundo, a semejanza de la verticalidad, funciona para que las palabras, las imágenes, los pensamientos, en ascenso y descenso, se comparen, se intercepten en la conciencia hasta manifestarse en el poema» (p. 105).

En este sentido, Eraso comprueba que Juarroz es un poeta mayor en el panorama de las letras hispanoamericanas, para tal propósito comparte cuatro capítulos clave que vislumbran lo emblemático de su artificio lírico publicado bajo el título de Poesía vertical (catorce poemarios publicados entre 1958 y 1997), su dirección en la revista Poesía=Poesía (1958-1965), así como también su extenso trabajo como reseñista en La Gaceta de Tucumán (1958-1963). Cada una de estas etapas marcó una huella importante y aunque durante el siglo XX su trabajo poético y crítico no tuvo mayor recensión, no significa que en la actualidad acredite menor atención. De esta manera, desde la introducción del texto, Eraso plantea la hipótesis sobre "la comunión de las formas", con el objeto de resaltar la importancia que tiene su poesía para Argentina e Hispanoamérica, porque «Juarroz dejó establecido un lazo entre el asombro y la conciencia de estar sometido a la gravedad. El aire de la melancolía, desolación y violencia, enunciado a veces en sus versos, muestra que no fue ajeno a la angustia que supone ser poeta y escribir poesía» (p. 10); aquella búsqueda por hallar la verticalidad fue lo que le permitió conocer la intensidad del misterio, que para él, es la verdad y la realidad. 
En el primer apartado, Eraso pone en relieve el hito (dimensión vertical) que marca la trascendencia de la poesía juarrociana. Para ello, el crítico colombiano no prescinde de estudiar con rigor los recursos figurativos por los que el poeta argentino pone de manifiesto su locus estético, puesto que su «escritura está impregnada de tensión semántica. Paradojas, anáforas, antítesis, oxímoros, los desencuentros entre el adentro y el afuera, el arriba y el abajo — en sentido general, la verticalidad — son algunos de los elementos que dan forma a la gestación de contrarios, gravitando en torno a un eje invisible» (p. 29). Dicho pilar intangible, es lo que le permite al autor de este libro, expresar que la poesía de Juarroz no es ni hermética ni anecdótica, sino más bien es un "pensamiento estético" en el que confluye un diálogo de imágenes en mixtura (comunión de las formas), una poesía autosuficiente como diría Salvador Elizondo, en la que la vida desafía al abismo permanentemente; por eso, Eraso transcribe uno de los poemas de la Sexta poesía vertical:

He llegado a mis inseguridades definitivas.

Aquí comienza el territorio

Donde es posible quemar todos los finales

Y crear el propio abismo,

Para desaparecer hacia adentro (p. 37).

De lo anterior, cabe agregar que este es uno de los capítulos más significativos, ya que Eraso vislumbra el amalgamiento de sentidos que produce la poesía juarrociana. Por una parte, destaca el vuelo (aire) como imagen introspectiva, por otra, devela los compuestos que representan una posible realidad: la de la caída (abismo); ambas, se condensan en la verticalidad, porque el poeta argentino «encuentra en la gravedad la alusión perfecta, no obstante su carácter físico, para hacer familiar uno de sus pensamientos predilectos: el significado de la experiencia de la poesía o su profundidad» (p. 47).

De modo similar, en el segundo apartado el lector encontrará un mapeo sobre la dimensión figurativa que caracteriza la obra de Juarroz. Para Eraso, es significativo tratar el lenguaje poético porque es el que permite que la metáfora no desentone con la musicalidad y viceversa. Para el crítico, la anáfora, la epífora, la paradoja y la antítesis son, entre otros tropos, elementos que garantizan una obstinación retórica que permite acompasar lo inasible, en virtud de una realidad que va más allá de lo absurdo, lo incognoscible y lo no patente, por esta razón dice que «Juarroz ha podido restaurar lo quebrado, coser la incisión, mostrar que, si algo estaba perdido, su poesía ha logrado delinear en el eje vertical de donde se expande la visión de un mundo compacto, la armonía oculta; en su caso, la exaltación de la lucidez consiste en hacer trasparente la comunión de las formas» (Eraso, 2017, p. 77). 
Acto seguido, el lector encontrará un rastreo a fondo sobre la revista Poesía =Poesía que dirigió Juarroz junto a Mario Morales y Dieter Kasparek. En este acápite se evidencia la meticulosidad de Eraso con la que revisó los veinte números de la revista publicados entre 1958 y 1965 . Igualmente no descuida las características particulares de cada opúsculo: tamaño, carátula, separatas, epígrafes, traducciones, publicidad y sobre todo el contenido poético de quienes publicaron sus óperas primas en aquella época. Dichos aspectos fueron relevantes, porque marcaron el eje transversal de la poesía de Juarroz, y desde luego, su avecinamiento con Poesía vertical. En un inicio, esta propuesta se desligó del ánimo comercial, su propósito se centraba en alejarse del espectáculo literario y más bien de consolidarse como un medio cultural en Argentina, donde lo primordial fue publicar poemas de escritores jóvenes con exiguo renombre internacional, pero con indudable resonancia poética (p. 83). Fue una poesía que ulteriormente alcanzó su pureza y su compromiso consigo misma, como en el caso de Octavio Paz y de Antonio Porchia, quienes confiaron en este proyecto literario.

En "Las reseñas de Roberto Juarroz en La Gaceta de Tucumán”, se escudriña y reflexiona sobre las cuarenta y dos reseñas críticas que el poeta argentino publicó en el suplemento literario conocido como La Gaceta. En este apartado, Eraso señala que entre 1958 y 1963, el menester crítico de Juarroz amparaba el propósito de Poesía =Poesía, esto es, centrarse en los poetas jóvenes de Argentina de aquella época: Josefina Bustamante, Joaquín Giannuzzi, Héctor Yánover, Rodolfo Alonso, Francisco Urondo, O.W. de Lubicz Milosz, René Palacios More, Alfredo Veiravé, Sara Alicia Viola, José Isaacson, Emma de Cartosio, Arturo Álvarez Sosa, Betina Edelberg, Julio César Silvain, Osvaldo Rossler, Simón Kargieman, Arnoldo Liberman, entre otros; sobre todo, porque sus creaciones eran sugestivas en comparación con lo que se escribía en Latinoamérica y además coincidían con su proyecto poético: la verticalidad. «Pienso que, con esa imagen geométrica, Juarroz supo además, situarse al otro lado de la poesía comprometida. Él no se fijó en la realidad inmediata, sino en la profundidad, en lo que está más allá de lo evidente, de lo biográfico, de lo histórico. En una época revolucionaria y de cambios, Juarroz estuvo dispuesto a que la poesía evolucionara» (p. 123).

Finalmente, se puede decir que Poesía de Roberto Juarroz. La comunión de las formas de Mario Eraso es un libro de gran densidad investigativa, pues con tan solo leer las observaciones que hace a pie de página y el anexo que comparte al final del libro se puede ratificar su rigor académico. Por tanto, no sería venturoso decir que su trabajo crítico acredita ineludible consulta y que está dedicado a aquellos estudiosos que quieren encontrar con Juarroz un nuevo y singular sentido de lo que implica estudiar la poesía hispanoamericana: «Si el poder de un poeta se mide por su ambición y lucidez, Juarroz propuso una obra ambiciosa y lúcida, por lo cual merece figurar al lado de las voces representativas de la poesía contemporánea» (p. 109). 